\title{
Caddo Ceramic Vessels from the Loftis and Pearl Smith Sites in Harrison County, Texas
}

Timothy K. Perttula

Heritage Research Center, Stephen F. Austin State University

Bo Nelson

Heritage Research Center, Stephen F. Austin State University

Follow this and additional works at: https://scholarworks.sfasu.edu/ita

Part of the American Material Culture Commons, Archaeological Anthropology Commons, Environmental Studies Commons, Other American Studies Commons, Other Arts and Humanities Commons, Other History of Art, Architecture, and Archaeology Commons, and the United States History Commons

Tell us how this article helped you.

This Article is brought to you for free and open access by the Center for Regional Heritage Research at SFA ScholarWorks. It has been accepted for inclusion in Index of Texas Archaeology: Open Access Gray Literature from the Lone Star State by an authorized editor of SFA ScholarWorks. For more information, please contact cdsscholarworks@sfasu.edu. 
Caddo Ceramic Vessels from the Loftis and Pearl Smith Sites in Harrison County, Texas

\section{Creative Commons License}

\section{(c) (1) (8)}

This work is licensed under a Creative Commons Attribution-NonCommercial 4.0 International License 


\section{Caddo Ceramic Vessels from the Loftis and Pearl Smith Sites in Harrison County, Texas}

\section{Timothy K. Perttula and Bo Nelson}

\section{INTRODUCTION}

The Loftis (HC-53) and Pearl Smith (HC-60) sites are ancestral Caddo sites that were investigated by Buddy Jones, probably in 1960, but those investigations were never published by Jones. The sites are along Clarks Creek in the Sabine River basin in southwestern Harrison County in East Texas (Figure 1); Loftis is about $3 \mathrm{~km}$ north of the Pearl Smith site. Jones excavated Caddo burials from both sites, and also conducted limited investigations in Caddo habitation deposits at the Loftis site.

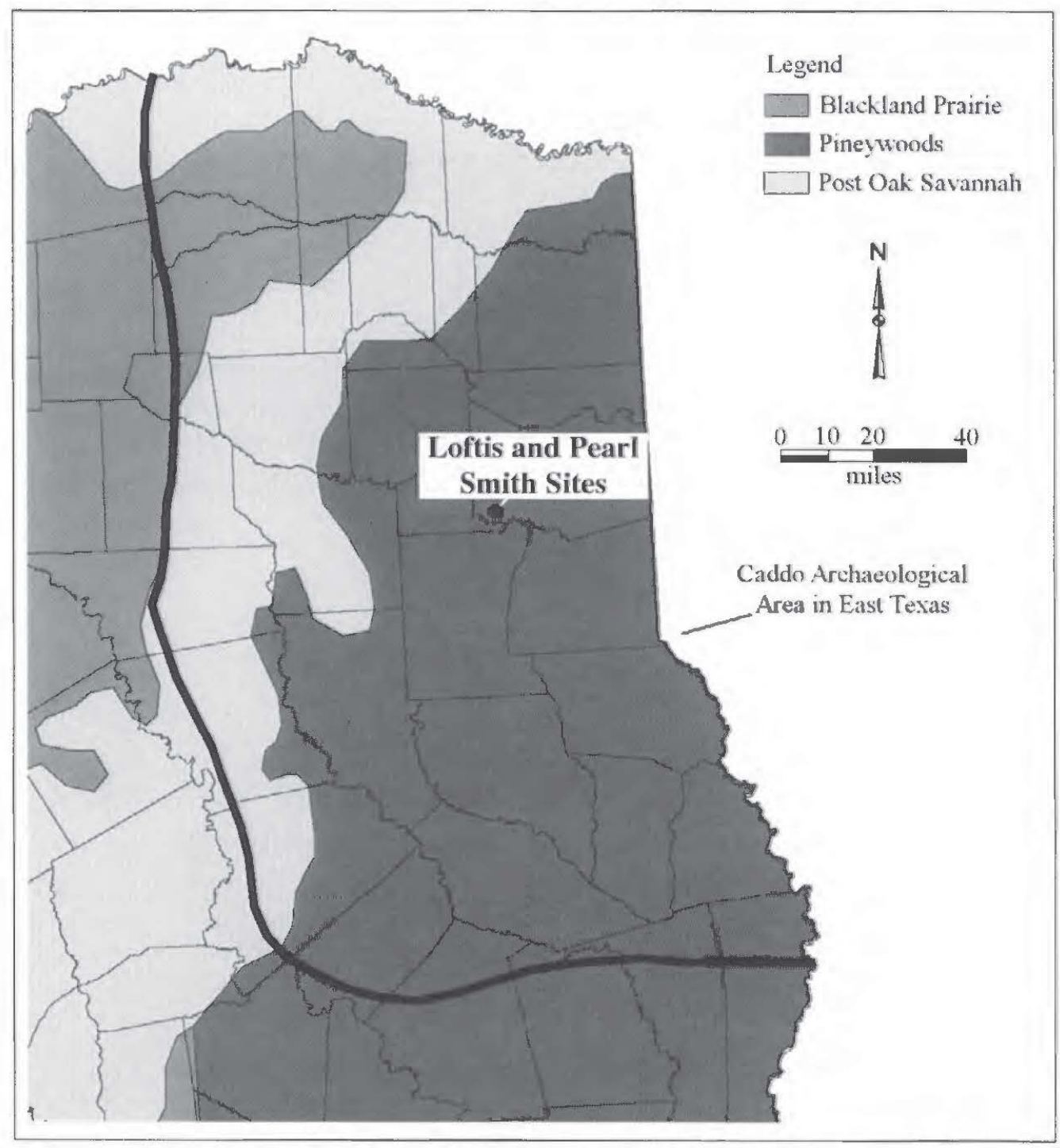

Figure 1. General location of the Loftis and Pearl Smith sites in East Texas. 
There are two vessels from the Loftis site and one vessel from the Pearl Smith site in the Buddy Jones collection at the Gregg County Historical Museum. There are no notes or plans of the burial features excavated by Jones at either site. Burials had apparently been excavated by several people at the Loftis site, including Jones, and the burials excavated at the Pearl Smith site may have been first discovered during construction of a new gas well on the site. Catalog information suggests that at least 17 Caddo burials were excavated at the Pearl Smith site.

\section{LOFTIS SITE VESSELS}

SITE NAME OR SITE NUMBER: Loftis

VESSEL NO.: 2003.08.854

VESSEL FORM: Jar with rim peaks and strap handles ( $23 \times 21 \mathrm{~mm}$ in length and width)

HEIGHT (IN CM): N/A

ORIFICE DIAMETER (IN CM): 21.0

DIAMETER AT BOTTOM OF RIM OR NECK (IN CM): 20.6

BASE DIAMETER (IN CM) AND SHAPE OF BASE: N/A

ESTIMATED VOLUME (IN LITERS): N/A

DECORATION (INCLUDING MOTIF AND ELEMENTS WHEN APPARENT): The rim has vertical brushed-incised marks and lines. The vessel body has appliqued circles repeated four times around the vessel. Each appliqued fillet circle has a central appliqued node. The circles are divided and connected by a series of upper and lower nested appliqued fillets, and there is a single horizontal appliqued fillet immediately below the rim-body juncture (Figure 2).

PIGMENT USE AND LOCATION ON VESSEL: none

TYPE AND VARIETY [IF KNOWN]: Harleton Appliqued

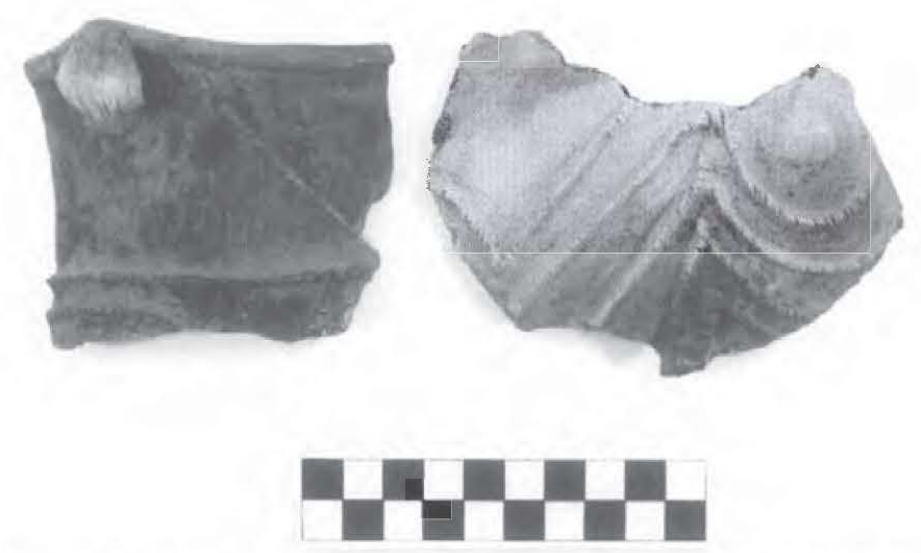

Figure 2. Harleton Appliqued jar rim and body sherds from the Loftis site. 
SITE NAME OR SITE NUMBER: Loftis

VESSEL NO.: 2003.08.855

NON-PLASTICS AND PASTE: grog

VESSEL FORM: Carinated bowl

HEIGHT (IN CM): N/A

ORIFICE DIAMETER (IN CM): 20.0

DIAMETER AT BOTTOM OF RIM OR NECK (IN CM): 19.6

BASE DIAMETER (IN CM) AND SHAPE OF BASE: N/A

ESTIMATED VOLUME (IN LITERS): N/A

DECORATION (INCLUDING MOTIF AND ELEMENTS WHEN APPARENT): The rim has a panel defined by upper and lower horizontal engraved lines. On the panel are a series of engraved ovals and semicircles marked by sets of closely-spaced lines.

PIGMENT USE AND LOCATION ON VESSEL: none

TYPE AND VARIETY [IF KNOWN]: Unidentified fine ware

\section{PEARL SMITH SITE VESSEL}

SITE NAME OR SITE NUMBER: Pearl Smith

VESSEL NO.: 2003.08.1533

NON-PLASTICS AND PASTE: grog and sandy paste

VESSEL FORM: Jar with four rim peaks

HEIGHT (IN CM): N/A

ORIFICE DIAMETER (IN CM): 14.0

DIAMETER AT BOTTOM OF RIM OR NECK (IN CM): 13.8

BASE DIAMETER (IN CM) AND SHAPE OF BASE: N/A

ESTIMATED VOLUME (IN LITERS): N/A

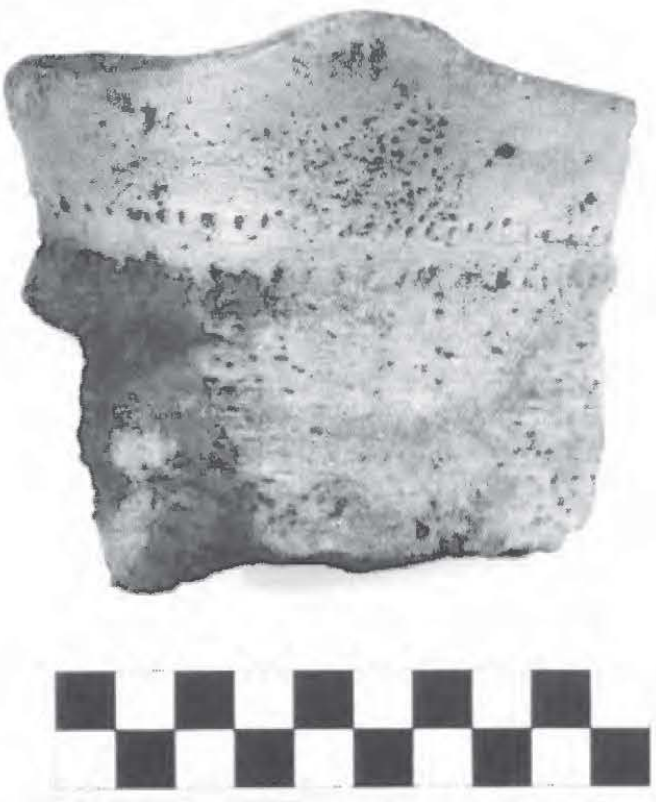

Figure 3. Brushed-punctated jar from the Pearl Smith site. 
horizontal brushing marks and two rows of tool punctations, one mid-rim and the other at the rim-body juncture. The vessel body has four panels defined by vertical rows of tool punctates. Each panel has a single triangle element outlined by six rows of tool punctates (Figure 3 ).

PIGMENT USE AND LOCATION ON VESSEL: none

TYPE AND VARIETY [IF KNOWN]: Unidentified utility ware

\section{SUMMARY AND CONCLUSIONS}

The three ancestral Caddo ceramic vessels from the Loftis and Pearl Smith sites on Clarks Creek likely come from post-A.D. 1450 Titus phase burials in settlements and cemeteries that are part of the recently defined Pine Tree Mound community (Fields and Gadus 2012:Figures 9.9 and 9.10) in the mid-Sabine River basin. Harleton Appliqued jars are a principal utility ware in Titus phase vessel assemblages, and brushedpunctated jars are also well represented in Titus phase vessel collections from sites in the mid-Sabine River and Big Cypress Creek basins. The one engraved fine ware vessel from the Loftis site has decorative elements - open panels, near vertical arcing lines and ovals, and closely-spaced engraved lines-consistent with some varieties of Poynor Engraved, a post-A.D. 1400 fine ware made in the upper Neches River basin in East Texas (Perttula 2011:Figure 6-64c-d). A stylistically similar carinated bowls was excavated from one of the burials at the Pine Tree Mound site (41HS15) (Fields and Gadus 2012:Figure 6.25).

\section{ACKNOWLEDGMENTS}

We thank Patti Haskins of the Gregg County Historical Museum for her help with the vessel documentation from the Loftis and Pearl Smith sites.

\section{REFERENCES CITED}

Fields, R. C. and E. F. Gadus (editors)

2012 Archeology of the Nadaco Caddo: The View from the Pine Tree Mound Site (41HS15), Harrison County, Texas. 2 Vols. Reports of Investigations No. 164. Prewitt and Associates, Inc., Austin.

Perttula, T. K.

2011 The Ceramic Artifacts from the Lang Pasture Site (41AN38) and the Place of the Site within an Upper Neches River Basin Caddo Ceramic Tradition. In Archeological Investigations at the Lang Pasture Site (4IAN38) in the Upper Neches River Basin of East Texas, assembled and edited by T. K. Perttula, D. B. Kelley, and R. A. Ricklis, pp. 145-320. Archeological Studies Program Report No. 129, Texas Department of Transportation, Environmental Affairs Division, Austin. 